\title{
Okul Öncesi Öğretmen Adaylarının Çocuk İstismarı ve İhmali Üzerine Farkındalık Düzeylerinin İncelenmesi ${ }^{1}$
}

\author{
Dr. Öğr. Üyesi Özlem OKYAY* \\ Abant İzzet Baysal Üniversitesi, Eğitim Fakültesi, Okul Öncesi Öğretmenliği, Bolu / Türkiye, \\ ozlemokyay@yahoo.com, ORCID: 0000-0003-0916-8005 \\ Dr. Öğr. Üyesi Dilek EROL \\ Uşak Üniversitesi, Eğitim Fakültesi, Okul Öncesi Öğretmenliği, Uşak / Türkiye, \\ dilekerol@gmail.com, ORCID: 0000-0002-5565-586X
}

\section{$\ddot{O} z$}

İstismar ve ihmalin önlenmesi, çocuk haklarının ihlalini ortadan kaldırdığı gibi sağlıklı toplumların oluşmasında da son derece önemlidir. İstismar sorununun önlenmesinde çocuklarla aileleri kadar vakit geçiren öğretmenler kilit role sahiptir. Bu araştırmanın amacı; okul öncesi öğretmen adaylarının, ülkemizde her geçen gün sayısı artan çocuk istismarı ve ihmali sorununa yönelik farkındalık düzeylerini belirlemektir. Tarama deseninin kullanıldığı çalışmada, 2016-2017 eğitim öğretim yılında Bolu Abant İzzet Baysal Üniversitesi okul öncesi eğitimi öğretmenliği bölümünde öğrenim gören 135 öğretmen adayı ile gerçekleştirilmiştir. Araştırmanın verileri, 20 maddeden oluşan “Çocuk İstismarı ve İhmali Farkındalık Ölçeği”nin öğretmen adaylarına uygulanması ile toplanmıştır. Verilerin analizi sonucunda, okul öncesi öğretmen adaylarının çocuk istismarı ve ihmaline yönelik farkındalık düzeylerinin yüksek olduğu, kadın öğretmen adaylarının fiziksel istismara yönelik farkındalık düzeylerinin erkek

\footnotetext{
${ }^{1}$ Bu çalışma Uluslararası Çocuk Hakları Kongresi'nde bildiri olarak sunulmuştur (5-7 Ekim 2017, Düzce).

* Sorumlu Yazar. Tel: +90 3742541000

Makale Tarih Bilgisi. Gönderim: 16.06.2020, Kabûl: 12.12.2020, Basım: Aralık, 2021

(C) 2021. Kalem Eğitim ve Sağlık Hizmetleri Vakfı. Bütün Hakları Saklıdır. ISSN: 2146-5606, e-ISSN: $2687-6574$.
} 
öğretmen adaylarına göre ikinci sınıfların farkındalık düzeylerinin diğer sınıflara göre daha yüksek olduğu bulunmuş̧tur. Araştırmada elde edilen bulgular alanyazın ışığında tartışılmıştır.

Anahtar Kelimeler: Çocuk istismarı ve ihmali; Çocuk hakları; Farkındalık; Okul öncesi öğretmeni; Öğretmen adayları.

\title{
A Review of the Pre-school Teacher
}

\section{Candidates Levels of Awareness}

\section{About Child Abuse and Neglect}

\begin{abstract}
The teachers play a major part in preventing child abuse and neglectan important social problem. The prevention of abuse and neglect would protect children's rights against violations and is extremely crucial in ensuring healthy societies. The objective of the present study is tounder stand the preschool teacher candidates level of awareness about the ever increasing numbers of child abuse and neglect. The study employed a survey pattern and was carried out with 135 teacher candidates enrolled at the preschool teacher training department of Bolu Abant İzzet Baysal University, in academic year 2016-2017. The data were gathered through the application of the 20-item "Child Abuse and Neglect Awareness Scale" with the teacher candidates. The analysis of the data revealed that the preschool teacher candidates had a high level of awareness about child abuse and neglect, that the awareness levels of female teacher candidates were particularly higher compared to those of the male ones, and that the awareness levels of the sophomore year teacher candidates were higher compared to the other years. The findings reached through the study are then discussed in the light of theliterature. Keywords: Child abuse and neglect; Child rights; Awareness; Preschool teachers; Teachers candidates.
\end{abstract}

\section{Extended Summary}

\section{Purpose}

Pre-school teachers who spend a lot of time with children, engaging in direct communication with them, obviously play a major part in identifying children who suffer from abuse and neglect, and in raising awareness among the families. Providing detailed information about this matter to pre-service teachers will only help them play a more effective part in preventing and treating abuse during their service. Assessing the pre-service teachers' awareness and knowledge levels regarding this issue will provide guidance for 
reinforcing of the programs to help their training and contribute to the literature. In response, this study aims to analyze the pre-service preschool teachers' awareness levels regarding abuse and neglect, with reference to a number of variables (gender, year in the program, level of satisfaction with the higher education program, level of knowledge about abuse and neglect).

\section{Method}

The study employed a survey pattern and was carried out with 135 prospective teachers enrolled at the pre-school teacher training department of Bolu Abant İzzet Baysal University, in academic year 2016-2017. The data were gathered through the "General Information Form" and the "Child Abuse and Neglect Awareness Scale" applied with pre-service teachers. Mann Whitney $\mathrm{U}$ and Kruskal Wallis tests were used to compare awareness scores of variables that do not have a normal distribution.

\section{Results}

The average scores the pre-service teachers from the whole scale and the physical abuse dimension were examined. It was determined that there is a significant difference according to the gender variable. In this context, one can argue that women have higher levels of awareness, compared to those of men. With reference to the year the pre-service teacher is enrolled in, the sophomores were found to exhibit higher levels of awareness compared to seniors. Furthermore, the pre-service teachers who were satisfied with the higher education program they were enrolled in were found to have higher levels of awareness about child abuse and neglect, compared to pre-service teachers who were not. In the same vein, pre-service teachers who considered themselves to be knowledgeable about the matter also exhibited higher levels of awareness compared to those who did not.

\section{Discussion}

In the study, there is a significant difference regarding the gender variable in the physical abuse sub-dimension and total score of the scale. Studies conducted by Uysal and Özsoy (2003), Kürklü (2011), Pala (2011), CanYaşar, Şenol and Akyol (2015), it is seen that the gender variable does not make a significant difference in the awareness levels of the participants regarding child neglect and abuse. Thus, one can forcefully argue that gender does not play a significant part in determining awareness levels about child abuse and neglect, regardless of the differences in terms of the study groups, methods and tools employed in the studies. The findings regarding the year of 
enrollment suggest that sophomore pre-service teachers have higher levels of awareness compared to senior-year ones. In the study conducted by CanYaşar, Kızıltepe and Kandır (2014) and Tezdiğ (2017), it was concluded that the awareness of teacher candidates in the $4^{\text {th }}$ grade about child abuse and neglect was higher than the pre-service teachers in other classes. In the light of the literature, one can argue that more studies regarding this variable are needed, and that further analyses of awareness levels about abuse and neglect with reference to the year of enrollment are needed. It was also observed that pre-service teachers who were satisfied with the higher education program they were enrolled in had higher levels of awareness about child abuse and neglect, compared to pre-service teachers who were not satisfied with the program. Other studies in the literature (Kanak, 2015; Pala, 2011; Tugay, 2008; Walsh, 2005) also suggest that teachers and pre-service teachers trained about child abuse and neglect had higher levels of knowledge and awareness compared to those who did not receive such trainings. Their findings are in line with those of the present study. The pre-service teachers who considered themselves to be knowledgeable about child abuse and neglect were found to have higher levels of awareness about the issue. A glance at the literature (Sağır and Gözler, 2013; Tezdiğ, 2017; Tugay, 2008) reveals that teachers usually lacked adequate knowledge about child abuse and neglect and needed training about the problem. The fact that pre-service teachers who were better informed about the issue exhibit higher levels of awareness underlines the importance of pre-service training and education.

\section{Conclusion}

In the light of the study, one can forcefully argue that training about child abuse and neglect contributes to increasing awareness and knowledge levels of the individuals. The findings reached support the recommendation that awareness levels of pre-service teachers can be reinforced through academic events (seminars, panels, and symposia) discussing child abuse and neglect, as well as increased emphasis on the matter in the curricula of faculties of education training pre-service teachers. Future studies are expected to compare the knowledge and awareness levels of pre-service teachers trained about child abuse and neglect, before and after the relevant trainings. 


\section{Giriş}

Çocuğa bakmakla yükümlü kişi ya da kurumlar tarafindan gerçekleştirilen çocuk istismarının geçmişi insanlık tarihi kadar eskiye dayanmaktadır. Çocuk istismarı ve ihmalinin birçok nedeni bulunmaktadır. Alandaki çalışmalarda ortaya çıkan nedenler; çocuğun ayrı birey olarak görülmemesi, kendini yeterince ifade edememesi, yetişkinin çocuk üzerinde sınırsız haklara sahip olduğunu düşünmesi gelmektedir (Fortson ve ark., 2016; Krug ve ark., 2002; Thomas ve ark., 2002). Yıllar içindeki toplumsal gelişmeler çocuğa bakış1 değiştirmiş, yaşanan bu olaylar bir sorun olarak görülmeye başlanmış ve 1960'lı yıllarda, istismar artık toplumsal bir problem olarak tanımlanmaya başlamıştır. 1962 yılında Kempe ve arkadaşlarının yayınladıkları çalışmada, bir yıl içinde 302 çocuk istismarı olgusu tespit edildiği; bu olgulardaki 33 çocuğun öldüğünü ve \%85'inin ise beyninde kalıcı lezyon bulunduğunu belirtmişlerdir. Bir başka deyişle Kempeve arkadaşları (1962), çocukların en temel hakkı olan yaşam hakkının tehlikede olduğunu ilk kez gözler önüne sermiştir. Alandaki ilk çalışmadan bugüne, konu hakkında toplumsal farkındalık uyanmaya başlasa da sorun, gelişmişlik düzeyinden bağımsız olarak birçok ülkede bugün dahi varlığını göstermektedir (Kars, 1996; Polat, 2007; WHO, 2017).

Alanda yapılan çalışmalar (Bilir ve ark., 1991; Kars, 1996; Koç ve ark., 2012), çocukların en çok istismara uğradıkları yaş aralığının 0-6 olduğunu göstermektedir. Bireyin en savunmasız yaş aralığı olan 0-6 yaş dönemi aynı zamanda bireyin tüm gelişim alanlarında en hızlı büyüme ve gelişme gösterdiği dönem olarak bilinmekte ve kabul edilmektedir (Robbins ve ark., 2012). Başta bu kritik dönem olmak üzere, çocukların 18 yaşına kadar her türlü kötü muameleden korunması devletlerin en önemli sorumlulukları arasında yer almaktadır.

Devletler, çocukları gerek aile içinde gerekse de aile dışında yaşadıkları istismar ve ihmalden korumak için çeşitli istismar ve ihmali önleme çalışmaları yürütmektedir. Genel olarak alanyazında istismar ve ihmalden koruma önlemleri üç ana başl1kta incelenmektedir. Birincil önleme, istismar ve ihmal ortaya çıkmadan yapılan çalışmaları, ikincil önleme soruna yönelik erken tanı ve tedaviyi, üçüncül önleme ise istismar ya da ihmale uğramış çocukların sağaltım çalışmalarını kapsamaktadır (Turhan, Şangün ve İnand1, 2006).

Hart, Gunnar ve Cicchetti (1996) çocuk istismarını önlemek için okulların merkezi bir öneme sahip olduklarını, okul personelinin çocukların normal ve normal dışı davranışlarını gözlemleyerek istismarın tespitinde önemli 
bir rol oynadıklarını belirtmişlerdir. 2007 yılında Avrupa Konseyi tarafından ele alınan "Çocuklara Yönelik Her Türlü Fiziksel Ceza Uygulamasının Ortadan Kaldırılması" adlı raporda çocukların korunması için çocuk yararına politikalar geliştirilmesinin ve yapısal reformların gerekliliği vurgulanmıştır. Çalışmada ayrıca anne-babaların, çocuklarla vakit geçiren uzmanların (öğretmen, doktor gibi), çocukların ve toplumun bilgilendirilmesinin önemi açıklanmıştır (Avrupa Konseyi, 2007).

Alanyazında öğretmen ve eğitimcilerin istismarı önlemedeki rolleri, istismarı nasıl ihbar edecekleri ve yasal sorumluluklarının neler olduğu hakkında bilgilendirilmeleri üzerine birçok çalışma yapılmıştır (Abrahams, Casey ve Daro, 1992; Fraser, 1981; Karaman, 1993; McEvoy, 1990; McGrath ve ark., 1987; McIntyre, 1990). Bu çalışmalar istismar ve ihmali önlemede öğretmenlerin bilgilendirilmelerinin önemini ortaya koymaktadır.

Türk eğitim sisteminde okul öncesi öğretmenleri 36-72 aylık çocuklarla en az 30 saat birlikte vakit geçirmektedir, özel eğitim kurumundaki okul öncesi öğretmenlerinin çocuklarla birlikte geçirdikleri zaman ise 50 saate yaklaşabilmektedir. Çocuğun eğitiminin önemli bir zaman dilimine sahip okul öncesi öğretmenlerinin, çocukları etkili bir şekilde gözlemleyerek risk durumlarını belirleme, gerekli yasal bildirimlerde bulunma, çocukların tedavi süreçlerine aktif olarak katılma gibi önemli rolleri bulunmaktadır (Dilsiz ve Mağden, 2015). Toplumun çocuk istismarı konusunda duyarlılığını arttırmak, sınıflarındaki çocukların anne babalarını ve diğer bireyleri eğitmek konusunda da öğretmenlerin önemli görevleri bulunduğundan öğretmenlerin lisans eğitimlerinde önemle ele alınması gerekmektedir (Şahin ve Beyazova, 2001; Türkoğlu ve Gültekin-Akduman, 2013). Sonuç olarak çocuklarla her gün bu kadar yoğun zaman geçiren ve birebir ilişki içinde olan okul öncesi öğretmenlerinin, istismara uğrayan ve ihmal edilen çocukları belirlemede, aileleri bu konuda bilinçlendirmedeki rolleri oldukça önemlidir. Hizmet öncesi dönemde öğretmen adaylarının konu hakkında bilgilendirilmesi, geleceğin öğretmenlerinin istismarın önlenmesi ve tedavisi konusunda daha etkin rol oynamalarını sağlayacaktır. Öğretmen adaylarının bu konuda bilgilerinin ve farkındalıklarının tespiti, lisans ve lisansüstü programlarında ders içeriklerinin oluşturulmasına katkı sunacağından alanın gelişmesine katkı sağlayacaktır.

Araştırma, okul öncesi öğretmenliği lisans öğrencilerinin çocuk istismarı ve ihmali konusundaki farkındalık düzeylerini incelemek amacıyla gerçekleştirilmiştir. 


\section{Yöntem}

\section{Araştırma Modeli}

Betimsel bir araştırma yönteminin benimsendiği bu çalışmada tarama modeli kullanılmıştır. Araştırmada belirlenen olayın kendi koşulları içinde var olduğu şekliyle tanımlanmaya çalışıldığı tarama modelinde, katılımcıların görüşleri betimlenmeye çalışılmaktadır (Büyüköztürk ve ark., 2016; Karasar, 2005).

\section{Çalışma Grubu}

Araştırmanın çalışma grubunu 2016-2017 eğitim öğretim döneminde Abant İzzet Baysal Üniversitesi Okul Öncesi Eğitimi Öğretmenliği programında öğrenim gören 135 öğretmen adayı oluşturmuştur. Uygun örnekleme yöntemi ile seçilen katılımcıların \%91.9'u kadın, \%8.1'i erkektir. \%37'si ikinci sınıfta, \%21.5'i üçüncü sınıfta, \%41.5'i dördüncü sınıfta öğrenim görmektedir.

\section{Veri Toplama Araçları}

Araştırmada öğretmen adaylarının demografik özellikleri için "Genel Bilgi Formu" istismar ve ihmal konusundaki farkındalıkları belirlemek amacyyla Altan (2015) tarafindan geliştirilen "Çocuk İstismarı ve İhmali Farkındalık Ölçeği (Çİ̈F-Ö)" kullanılmıştır.

\section{Genel Bilgi Formu}

$\mathrm{Bu}$ formda öğretmen adayının yaşı, cinsiyeti, öğrenim gördüğü sınıf, lisans programını yeterli bulma durumu, çocuk ihmal ve istismarı konusunda bilgi sahibi olma durumları ile ilgili sorular yer almaktadır.

\section{Çocuk İstismarı ve İhmali Farkındalık Ölçeği (ÇİïF-Ö)}

4 alt grup (fiziksel istismar, cinsel istismar, duygusal istismar ve ihmal) altında toplanan "Çocuk istismarı ve İhmali Farkındalık Ölçeği (Çİ̈F-Ö)" 11 'i olumsuz, 9'u olumlu 20 maddeden oluşmaktadır. Kısa senaryolar şeklinde hazırlanan ölçek çocuk istismarının tipleri olan fiziksel istismar, cinsel istismar, duygusal istismar ve ihmal alt boyutlarına ayrılmıştır. Ölçek maddelerinin sade ve anlaşılır bir dille ifade edilmesine ve bir maddede birden fazla yargı ve düşünce olmamasına dikkat edilmiştir. 5'li likert tipinde ("kesinlikle uygun değil-1" ile "kesinlikle uygun-5") hazırlanan ölçekteki olumsuz maddeler tersten puanlanmıştır. Ölçekten alınacak en yüksek puan 100, en düşük puan 20 'dir. Alt ölçeklerin her biri 25 puandır. Güvenirlik için yapılan iç tutarlılık analizinde Cronbach Alfa değeri 0.768 olarak bulunmuştur (Altan, 2015). 


\section{Verilerin Analizi}

"Çocuk İstismarı ve İhmali Farkındalık Ölçeği (ÇİIF-Ö)" ile Genel Bilgi Formundan elde edilen veriler SPSS 20 programı ile analiz edilmiştir. Analizler öncesinde veri setinde kayıp değer incelemesi yapılmış ve herhangi bir kayıp değere rastlanmamıştır. Veri analizi için öncelikle betimsel istatistikler hesaplanmış, ardından verilerin parametrik test varsayımlarını sağlayıp sağlamadığı kontrol edilmiştir. Bunun için çalışma grubu sayısının 50'den fazla olması sebebiyle Kolmogorov-Smirnov testi kullanılmıştır. Ayrıca, dağılıma ait çarpıklık ve basıklık değerleri de incelenmiştir. Bu analizler 1ş1ğında; normal dağılıma sahip olmayan ve varyansları homojen özellik göstermeyen değişkenlerin farkındalık puanlarının karşılaştırılmasında Mann Whitney U ve Kruskal Wallis Testi kullanılmıştır.

\section{Bulgular ve Tartışma}

$\mathrm{Bu}$ bölümde, öğretmen adaylarının çocuk ihmal ve istismarına yönelik farkındalık düzeyleri farklı değişkenlerin varlığında incelenmiş ve araştırma bulguları 1şığında yorumlanmıştır.

Tablo 1. Çalışma Grubunun Çocuk İstismarı ve İhmali Farkındalık Düzeylerine İlişkin Betimsel İstatistikler

\begin{tabular}{lcc}
\hline & $\overline{\mathbf{x}}$ & $\mathbf{s s}$ \\
\hline Fiziksel İstismar & 22.42 & 2.70 \\
Cinsel İstismar & 19.46 & 2.40 \\
Duygusal İstismar & 19.06 & 2.11 \\
İhmal & 22.36 & 1.73 \\
\hline Toplam & 83.30 & 5.99 \\
\hline
\end{tabular}

Tablo 1'de öğretmen adaylarının ölçekten aldıkları puan ortalamaları incelendiğinde, çocuk ihmal ve istismarına ilişkin farkındalık düzeylerinin yüksek olduğu $(\overline{\mathrm{x}}=83.30)$ belirlenmiştir.

Ölçeğin alt boyutlarından elde ettikleri puan ortalamaları incelendiginde ise fiziksel istismar ( $\overline{\mathrm{x}}=22.42)$, cinsel istismar $(\overline{\mathrm{x}}=19.46)$, duygusal istismar $(\overline{\mathrm{x}}=19.06)$ ve ihmal $(\overline{\mathrm{x}}=22.36)$ boyutlarında da farkındalık düzeylerinin yüksek olduğu, fiziksel istismar ve ihmale yönelik farkındalık düzeylerinin cinsel ve duygusal istismara yönelik farkındalık düzeylerinden daha yüksek olduğu bulunmuştur. Konuya ilişkin alanyazın (Altan, 2015; Pala, 2011; Tugay, 2008) incelendiğinde öğretmen adayları ve öğretmenlerin çocuk ihmal ve istismarına yönelik özellikle kanunen bildirimde bulunulması gerektiği konusundaki farkındalık düzeylerinin yüksek olduğu sonucuna ulaşılmıştır. Araştırmaya paralel olarak Dönmez'in (2009) yürüttüğü çalışmada da okul öncesi 
öğretmenlerinin çocuk istismarı ve ihmali konusunda farkındalık düzeylerinin yüksek olduğu belirlenmiştir. Araştırma bulgularının alanyazındaki diğer araştırmaların sonuçlarıyla örtüştügü görülmektedir. Bu bulgulardan hareketle, öğretmen adaylarının çocuk istismarı ve ihmali konusunda farkındalık düzeylerinin yüksek olduğu söylenebilir.

Tablo 2. Çalışma Grubunun Cinsiyete Göre Çocuk İstismarı ve İhmali Farkındalık Puanlarına İlişkin Mann Whitney U Testi Sonuçları

\begin{tabular}{lllllll}
\hline & & & \multicolumn{5}{c}{ Mann Whitney U Testi } \\
\cline { 5 - 7 } Alt Boyutlar & Cinsiyet & $\mathbf{N}$ & Sira Ort. & $\mathbf{Z}$ & $\mathbf{U}$ & $\boldsymbol{p}$ \\
\hline Fiziksel & Kadın & 124 & 71.04 & -3.080 & 305 & $.002^{*}$ \\
İstismar & Erkek & 11 & 33.73 & & & \\
\hline Cinsel & Kadın & 124 & 68.68 & -.682 & 598 & .495 \\
İstismar & Erkek & 11 & 60.36 & & & \\
\hline Duygusal & Kadın & 124 & 68.51 & -.517 & 618.5 & .605 \\
İstismar & Erkek & 11 & 62.23 & & & \\
\hline İhmal & Kadın & 124 & 69.34 & -1.365 & 515.5 & .172 \\
& Erkek & 11 & 52.86 & & & \\
\hline Toplam & Kadın & 124 & 70.01 & -2.011 & 432.5 & $.044^{*}$ \\
& Erkek & 11 & 45.32 & & & \\
\hline
\end{tabular}

$\overline{p<.05}$

Tablo 2 incelendiğinde, ölçeğin fiziksel istismar alt boyutu $(\mathrm{U}=305, \mathrm{z}=-$ $3.080, p=0.002)$ ve toplam puaninda $(\mathrm{U}=432.5, \mathrm{z}=-2,011, p=0.044)$ cinsiyet değişkenine ilişkin anlamlı bir farklılık bulunmaktadır $(p<.05)$. Cinsel istis$\operatorname{mar}(\mathrm{U}=598, \mathrm{z}=-.682, p=0.495)$, duygusal istismar $(\mathrm{U}=618,5, \mathrm{z}=-517$, $\mathrm{p}=0.605)$, ihmal $(\mathrm{U}=515.5, \mathrm{z}=-1.365, p=0.172)$ alt boyutlarında ise anlamlı bir fark bulunmadığı görülmektedir ( $p>.05)$. Puan ortalamaları incelendiğinde, tüm alt boyutlar için kadın öğretmen adaylarının çocuk istismarı ve ihmaline ilişkin farkındalık düzeylerinin erkek öğretmen adaylarından daha yüksek olduğu belirlenmiştir.

Uysal ve Özsoy'un (2003) yaptığı çalışmada, öğretmenlerin cinsiyetleri ile çocuk ihmal ve istismarına ilişkin görüşleri arasında istatistiksel açıdan anlamlı bir ilişkinin olmadığı belirlenmiştir. Kürklü (2011) yaptığı çalışmada cinsiyetin öğretmenlerin çocuk istismarı ve ihmalinin belirti ve riskleri tanılamada etkisinin olmadığını ortaya çıkarmıştır. Pala (2011), Can-Yaşar, Şenol ve Akyol (2015) ve Altan'ın (2015) yaptıkları çalışmalar incelendiğinde de öğretmen adaylarının cinsiyetleri ile çocuk ihmal ve istismarı konusundaki bilgi, tutum ve farkındalık düzeyleri arasında istatistiksel açıdan anlamlı bir farkın olmadığı tespit edilmiştir. Tezdiğ'in (2017) öğretmen adaylarının çocuk istismarı ve ihmaline ilişkin farkındalık düzeylerini incelediği araştırmasında 
ise kadın öğretmen adaylarının farkındalık düzeylerinin erkek öğretmen adaylarından istatistiksel olarak daha yüksek olduğu sonucuna ulaşılmıştır. CanYaşar, İnal-Kızıltepe ve Kandır (2014) öğretmen adaylarının çocuklardaki fiziksel istismar belirtilerine yönelik farkındalıklarını inceledikleri çalışmada; cinsiyet değişkeni anlamlı bir farklılık oluşturmasa da kadın öğretmen adaylarının puanlarının erkek öğretmen adaylarının puanlarından yüksek olmasına dikkat çekilerek kadınların toplumsal cinsiyet eşitsizliği nedeniyle farkındalık düzeylerinin daha yüksek olduğunu ortaya koymuşlardır. Araştırma bulguları Tezdiğ (2017), Can-Yaşar ve arkadaşlarının (2014) çalışmalarıyla benzer özellikler göstermektedir. Alanyazında incelenen araştırmaların çalışma grupları, yöntemleri ve ölçme araçlarının farklılık gösterse de cinsiyetin çocuk istismarı ve ihmali konusundaki farkındalığı etkileyen bir unsur olmadığı söylenebilir.

Tablo 3. Öğretmen Adaylarının Sınıf Düzeylerine Göre Çocuk İstismarı ve İhmali Konusundaki Farkındalık Puanlarına İlişkin Kruskal Wallis Testi Sonuçları

\begin{tabular}{lllllll}
\hline & $\mathbf{N}$ & Sira ort. & sd & $\mathbf{x 2}$ & $\boldsymbol{p}$ & Anlaml fark \\
\hline Fiziksel İstismar & 50 & 68.68 & 2 & .327 & .849 & Yok \\
& 29 & 70.79 & & & & \\
& 56 & 65.95 & & & & \\
\hline Cinsel İstismar & 50 & 84.09 & 2 & 14.38 & $.001^{*}$ & $2-3,2-4$ \\
& 29 & 63.40 & & & & \\
& 56 & 56.02 & & & & \\
\hline Duygusal & 50 & 70.55 & 2 & .619 & .734 & Yok \\
İstismar & 29 & 69.53 & & & & \\
& 56 & 64.93 & & & & \\
\hline İhmal & 50 & 77.92 & 2 & 8.787 & $.012^{*}$ & $3-4$ \\
& 29 & 87.68 & & & & \\
& 56 & 93.05 & & & & \\
\hline Toplam & 50 & 77.33 & 2 & 7.558 & $.023^{*}$ & $2-4$ \\
& 29 & 72.74 & & & & \\
\hline$p<.05$ & 56 & 57.21 & & & &
\end{tabular}

Tablo 3'te öğretmen adaylarının "Çocuk İstismarı ve İhmali Farkındalık Ölçeği”"nden aldıkları puan ortalamalarının sınıf değişkenine göre anlamlı bir farkl11ık oluşturup oluşturmadığ incelenmiştir. Tablo 5'e göre cinsel istis$\operatorname{mar}\left(\mathrm{x}^{2}(\mathrm{sd}=2, \mathrm{n}=135)=14.38, p<0.05\right)$ alt boyutunda 2 . siniflar ile 3 . ve 4 . s1nıflar arasında anlamlı bir farklılık bulunmaktadır. $\mathrm{Bu}$ alt boyuttan elde edilen puanlar incelendiğinde, 2. sınıfların cinsel istismara yönelik farkındalık düzeyleri 3. ve 4. siniflardan daha yüksektir. İhmal alt boyutunda $\left(x^{2}(s d=2\right.$, $\mathrm{n}=135)=8.787, p<0.05$ ) ise 3 . ve 4 . sinıflar arasinda anlamlı bir farklılık 
gözlenmiştir. Buna göre çocuk ihmali konusunda 3. sınıfların 4. sınıflara göre daha yüksek bir farkındalığa sahip olduğu görülmektedir. Ölçeğin toplamından $\left(\mathrm{x}^{2}(\mathrm{sd}=2, \mathrm{n}=135)=7.558, p<0.05\right)$ elde edilen puanlar incelendiğinde; 2 . sinıflar ile 4. sınıflar arasında anlamlı bir farklılık belirlenmiştir. Buna göre, 2. sınıfların çocuk istismarı ve ihmali konusundaki farkındalık düzeyleri 4. sınıflara göre yüksektir. Tezdiğ (2017) yaptığı çalışmada 4. sınıftaki öğretmen adaylarının çocuk istismarı ve ihmaline ilişkin farkındalıklarının 2. ve 3. s1nıftaki öğretmen adaylarından daha yüksek olduğu sonucuna ulaşılmıştır. Benzer şekilde Can-Yaşar ve arkadaşlarının (2014) yaptıkları çalışmadada 4. sınıftaki öğretmen adaylarının fiziksel istismar belirtilerini değerlendirme puanlarının 1. sınıflardan yüksek olduğu belirlenmiştir. Araştırma bulguları alanyazında incelenen araştırma bulguları ile paralellik göstermemektedir. $\mathrm{Bu}$ durum, çalışma grubunun yer aldığı lisans programında ikinci sınıfta alınan çocuk ruh sağlığı dersinin çocuk istismarı konusunu yoğunlukla ele alması, diğer derslerde bu konuya sınırlı düzeyde yer verilmesi ve çalışma grubunda 2. sınıfta yer alan öğretmen adaylarının konuya olan ilgisi ile açıklanabilir. Alanyazındaki çalışmalar incelendiğinde bu değişkene ilişkin çalışmaların sayısının oldukça yetersiz olduğu, istismar ve ihmale yönelik farkındalık düzeylerinin sınıf değişkenine göre incelenmesinin gerekliliği ortaya çıkmıştır.

Tablo 4. Öğretmen Adaylarının Lisans Programını Çocuk İstismarı ve İhmali Konusunda Yeterli Bulma Durumlarına Göre ÇİIFFA-Ö Puanlarına İlişkin Mann Whitney U Testi Sonuçları

\begin{tabular}{lllllll}
\hline & & & \multicolumn{4}{c}{ Mann Whitney U } \\
\cline { 5 - 7 } & Yeterli & $\mathbf{N}$ & Srra Ort. & $\mathbf{z}$ & $\mathbf{U}$ & $\boldsymbol{p}$ \\
\hline Fiziksel İstismar & Evet & 20 & 84.43 & -2.067 & 821.5 & .39 \\
& Hayır & 115 & 64.14 & & & \\
\hline Cinsel İstismar & Evet & 20 & 82.08 & -1.760 & 868.5 & .78 \\
& Hayır & 115 & 65.55 & & & \\
\hline Duygusal İstismar & Evet & 20 & 100.13 & -4.032 & 507.5 & $.000^{*}$ \\
& Hayır & 115 & 62.41 & & & \\
\hline İhmal & Evet & 20 & 92.73 & -3.121 & 655.5 & $.02^{*}$ \\
& Hayır & 115 & 63.70 & & & \\
\hline Toplam & Evet & 20 & 98.23 & -3.751 & 545.5 & $.000^{*}$ \\
& Hayır & 115 & 62.74 & & & \\
\hline$p<05$ & & & & & &
\end{tabular}

$\overline{p<.05}$

Tablo 4 incelendiğinde, okul öncesi öğretmenliği lisans programını çocuk istismarı ve ihmaline yönelik eğitim verme konusunda yeterli bulma durumu ile fiziksel $(\mathrm{U}=821.5, \mathrm{z}=-2.067, p=.39)$ ve cinsel istismar $(\mathrm{U}=868.5, \mathrm{z}=-$ $1.760, p=.78)$, alt boyutları arasında anlamlı bir fark gözlenmezken $(p>.05)$; ölçektoplamı $(\mathrm{U}=545.5, \mathrm{z}=-3.751, p=.000)$, duygusal istismar $(\mathrm{U}=507.5, \mathrm{z}=-$ 
4.032, $p=.000)$ ve ihmal $(\mathrm{U}=655.5, \mathrm{z}=-3.121, p=.02)$ alt boyutları arasinda bu değişken için anlamlı bir farklılık bulunmuştur $(p<.05)$. Buna göre ölçeğin toplamı, duygusal istismar ve ihmal alt boyutlarında lisans programını yeterli bulan öğretmen adaylarının yeterli bulmayanlara göre daha yüksek bir farkındalığa sahip oldukları söylenebilir.

Kanak (2015)'ın okul öncesi öğretmen adaylarının duygusal istismar ve ihmal konusundaki bilgi ve farkındalıklarına ilişkin destek eğitim programının etkisini incelemek için yaptığı çalışmada, eğitim alan grupta bulunan katılımc1ların program sonunda eğitim almayan gruptaki katılımcılara göre bilgi ve farkındalık düzeylerinde bir artış olduğu gözlenmiştir. Pala (2011) yaptığı çalışmada öğretmen adaylarının \%91.2'sinin ihmal ve istismarla ilgili eğitim almadığını, yine Can-Yaşar ve arkadaşlarının (2014) yaptığı çalışmada öğretmen adaylarının \% 85.73'ünün Çocuk Koruma Kanunu hakkında bilgi sahibi olmadığı, \%39.01'inin de fiziksel istismarın belirtilerini tanımlama konusunda kendilerinden emin olmadıkların belirttikleri görülmektedir. Walsh ve arkadaşları tarafından yapılan çalışmada (2005) ise öğretmenlerin \%93'ünün istismara dair eğitim aldıkları ve bu eğitim sonucunda öğretmenlerin ihmal ve istismarı tanımlama konusunda kendilerine tam olarak güvenmeseler de bildirim konusunda duyarlı davrandıkları belirlenmiştir. Tugay'ın (2008) yaptığı çalışmada, çalışma grubunu oluşturan öğretmenlerin \%93.8'inin konu ile ilgili eğitim almadığı, eğitim almanın istismar ve ihmali belirleme ve bildirimde bulunmada etkili olduğu sonucuna ulaşılmıştır. Öğretmenlerin istismar konusunda hem üniversite eğitimleri boyunca hem de hizmet içi eğitim hizmetlerinde yeterli eğitim alamadıkları görülmektedir (Aksel ve Yılmaz-Irmak, 2015; Erol, 2007). Dereobalı ve arkadaşlarının (2013) yaptıkları çalışmada, çocuklara uygulanan şiddet, istismar ve ihmal konusunda çok az sayıda eğitimcinin eğitim aldığı, bu eğitimin de lisans eğitimleri sırasında gerçekleştiği belirlenmiştir. Kürklü (2011)'nün yaptığı çalışmada ise katılımcı öğretmenlerin hem hizmet öncesi hem de hizmet sonrası süreçte çocuk istismar ve ihmali konusunda herhangi bir eğitim almadıklarını, çocuk koruma kanunu hakkında hiç bilgilendirilmediklerini belirttikleri, öğretmenlerin \%84.2'sinin $(n=203)$ bu konuda bilgilendirilme gereksinimi duyduklarını ifade ettikleri görülmektedir. Araştırma bulguları incelendiğinde çocuk istismarı ve ihmali konusunda lisans programındaki eğitimi yeterli bulan okul öncesi öğretmeni adaylarının farkındalık düzeylerinin daha yüksek olması alanyazındaki diğer araştırma sonuçları ile paralellik göstermektedir. Çocuk istismarı ve ihmali üzerine alınan eğitimin, bireylerin farkındalık ve bilgi düzeylerine olumlu etki sağladığı 
görülmektedir.

Tablo 5. Öğretmen Adaylarının Çocuk İstismarı ve İhmali Konusunda Kendilerini Bilgili Bulup Bulmamalarına Göre ÇİIF-Ö Puanlarına İlişkin Mann Whitney U Testi Sonuçları

\begin{tabular}{lllllll}
\hline & & & \multicolumn{4}{c}{ MannWhitney U } \\
\cline { 4 - 7 } & Bilgi Sahibi & $\mathbf{N}$ & Sira Ort. & $\mathbf{z}$ & $\mathbf{U}$ & $\boldsymbol{p}$ \\
\hline Fiziksel İstismar & Evet & 20 & 77.75 & -1.437 & 1163.5 & .151 \\
& Hayır & 115 & 65.67 & & & \\
\hline Cinsel İstismar & Evet & 20 & 87.71 & -2.886 & 904.5 & $.004^{*}$ \\
& Hayır & 115 & 63.30 & & & \\
\hline Duygusal İstismar & Evet & 20 & 93.98 & -3.819 & 741.5 & $.000^{*}$ \\
& Hayır & 115 & 61.80 & & & \\
\hline \multirow{2}{*}{ İhmal } & Evet & 20 & 81.37 & -1.976 & 1069.5 & $.048^{*}$ \\
& Hayır & 115 & 64.81 & & & \\
\hline Toplam & Evet & 20 & 93.08 & -3.645 & 765 & $.000^{*}$ \\
& Hayır & 115 & 62.02 & & & \\
\hline$p<.05$ & & & & & &
\end{tabular}

Tablo 5 incelendiğinde, öğretmen adaylarının istismar ve ihmal konusunda kendilerini bilgili bulma durumu ile fiziksel istismar alt boyutu $(\mathrm{U}=1163.5, \mathrm{z}=-1.437, p=.151)$ arasında manidar bir farklıl1k bulunmazken ( $p>.05)$, ölçek toplamı $(\mathrm{U}=765, \mathrm{z}=-3.645, p=.000)$, cinsel istismar $(\mathrm{U}=904.5$, $\mathrm{z}=-2.886, p=.004)$, duygusal istismar $(\mathrm{U}=741.5, \mathrm{z}=-3.819, p=.000)$ ve ihmal $(\mathrm{U}=1069.5, \mathrm{z}=-1.976, p=.048)$ alt boyutları arasinda anlamlı bir farkl111k belirlenmiştir $(p<.05)$. Ölçeğin toplamı, cinsel, duygusal istismar ve ihmal alt boyutlarında kendilerini ihmal ve istismar konusunda bilgili bulan adayların bulmayanlara göre daha yüksek bir farkındalığa sahip oldukları söylenebilir. Tugay'ın (2008) yaptığı çalışmada da fiziksel, cinsel istismar ve ihmali tanımlamada kendine daha güvenen öğretmenlerin kanunlara uygun olarak bildirim yapılmasının gerekliliğine inandıkları sonucuna ulaşılmıştır. Tezdiğ'in (2017) çalışmasında araştırmaya katılan öğretmen adaylarının büyük çoğunluğu (\%80.45) konu hakkında bilgi sahibi olduğunu belirtmiş ancak bu grubun çoğunluğu da varolan bilgilerinin yeterli düzeyde olmadığını da ifade etmişlerdir. İstismarın türleri konusunda öğretmenlerin \%58.36'sı bilgi sahibidir. Sağır ve Gözler'in (2013) sınıf öğretmenlerinin çocuk istismarı ve ihmaline yönelik görüşleri ve farkındalık düzeylerini inceledikleri araştırmalarında, çalışmaya katılan öğretmenlerin çoğunluğunun çocuk istismar ve ihmali konusunda herhangi bir eğitim almadıklarını, çocuk koruma kanunu hakkında bilgi sahibi olmadıklarını ve bu konuda bilgilendirilme ihtiyacı duyduklarını belirtmişlerdir. Araştırma sonuçları 1şığında, çocuk istismarı ve ihmali konusunda öğretmenlerin genellikle bilgi sahibi olmadıklarını ve eğitime ihtiyaç 
duyduklarını belirttikleri görülmektedir. Bu konuda bilgi sahibi olan öğretmen adaylarının ise çocuk istismarı ve ihmaline yönelik farkındalık düzeylerinin yüksek olması hizmet öncesindeki eğitimin önemini ortaya koymaktadır.

\section{Sonuç}

Bu çalışmada, okul öncesi eğitimi öğretmen adaylarının çocuk istismarı ve ihmaline yönelik farkındalık düzeylerininbazı değişkenler (cinsiyet, sınıf, lisans programını yeterli bulma durumu, ihmal ve istismar konusunda bilgi düzeyi) açısından incelenmesi amaçlanmıştır. Araştırma bulguları incelendiğinde, öğretmen adaylarının çocuk istismarı ve ihmaline yönelik farkındalık düzeylerinin yüksek olduğu $(\overline{\mathrm{x}}=83.30)$, cinsiyet değişkeninin istismar ve ihmal konusunda ölçeğin toplamı ve fiziksel istismar alt boyutunda kadın öğretmen adaylarının farkındalık düzeyinin erkek adaylardan daha yüksek olduğu görülmüştür. Ölçekten alınan toplam puanlar dikkate alındığında; ikinci s1nıfta öğrenim gören öğretmen adaylarının dördüncü sınıf öğretmen adaylarına göre farkındalıklarının daha yüksek olduğu, cinsel istismar alt boyutunda ikinci sınıfların yine üçüncü ve dördüncü sınıfa oranla bu konuda daha farkında oldukları, ihmal boyutunda ise üçüncü sınıfların dördüncü sınıflara oranla farkındalık düzeylerinin yüksek olduğu bulunmuştur. 4. sınıfların farkındalık düzeylerinin diğer sınıflara oranla daha düşük olması dikkat çekici bir bulgudur. Çocuk istismarı ve ihmali konusunda lisans programını yeterli bulanların bulmayanlara göre; bu alanda bilgi sahibi olduklarını düşünen öğretmen adaylarının bilgi sahibi olmayanlara göre farkındalık düzeylerinin yüksek olduğu sonucuna ulaşılmıştır. Araştırma bulguları 1şı̆̆ında; öğretmen yetiştiren eğitim fakültelerinin ders içeriklerinin çocuk istismarı ve ihmali konusunda geliştirilmesi, çocuk istismarı ve ihmaline yönelik bilimsel etkinlikler (seminer, panel, sempozyum gibi) düzenlenerek öğretmen adaylarının bu konudaki farkındalık düzeylerinin arttırılması, üniversite kütüphanelerinin çocuk istismarına yönelik yayınlarla zenginleştirilmesi, öğrenci topluluklarının bu konuda dikkat çekici çalışmalar planlaması önerilebilir. Bu konuda yapılacak sonraki çalışmalarda ise çocuk istismarı ve ihmali konusunda eğitim alan öğretmen adaylarının eğitim öncesi ve sonrasındaki bilgi ve farkındalık düzeyleri karşılaştırılabilir.

\section{Kaynakça}

Abrahams, N., Casey, K. ve Daro, D. (1992). Teachers' knowledge, attitudes, and beliefs about child abuse and its prevention. Child Abuse \& Neglect, 16(2), 229-238.

Aksel, Ş. ve Yılmaz-Irmak, T. (2015). Çocuk cinsel istismarı konusunda 
öğretmenlerin bilgi ve deneyimleri. Ege Eğitim Dergisi, 16(2), 373-391.

Altan, H. (2015). Üniversite ögrencisi gençlere çocuk istismarl ve ihmali konusunda yapılan eğitimin bilgi ve farkındalıklarına etkisi. Yayımlanmamış doktora tezi, Gazi Üniversitesi Sağlık Bilimleri Enstitüsü.

Avrupa Konseyi. (2007). Çocuklara yönelik fiziksel ceza uygulanmasının ortadan kaldirılmast.

https://rm.coe.int/168046d0b2

Bilir, Ş., Arı M., Dönmez, N. B. ve Güneysu, S. (1991). Çocuk istismarı ve ihmali: 412 yaşları arasındaki 16.100 çocukta örselenme durumu ile ilgili bir inceleme. Ankara: Gözde Repro Ofset.

Büyüköztürk, Ş., Kılıç-Çakmak, E., Akgün, Ö. E., Karadeniz, Ş. ve Demirel, F. (2012). Bilimsel araştırma yöntemleri (11. bask1). Ankara: Pegem Akademi.

Can-Yaşar, M., İnal-Kızıltepe, G. ve Kandır, A. (2014). Öğretmen adaylarının çocuklardaki fiziksel istismar belirtilerine ilişkin farkındalıkları. Kuramsal Eğitimbilim Dergisi, 7(3), 286-303.

Can-Yaşar, M., Şenol, F. B. ve Akyol, T. (2015). Öğretmen adaylarının çocuğa yönelik cinsel istismar tutumlarının incelenmesi. Hacettepe University Faculty of Health and Sciences Journal, 1(2), 228-241.

Dereobalı, N., Çırak-Karadağ, S. ve Sönmez, S. (2013). Okul öncesi eğitim öğretmenlerinin çocuk istismarı, ihmali, şiddet ve eğitimcilerin rolü konusundaki görüşleri. Ege Eğitim Dergisi, 14(1), 50-66.

Dilsiz, H. ve Mağden, D. (2015). Öğretmenlerin çocuk istismar ve ihmali konusunda bilgi ve risk tanıma düzeylerinin tespit edilmesi. Hacettepe Üniversitesi Sağllk Bilimleri Fakültesi Dergisi, 1(2), 678-694.

Dönmez, E. (2009). Okul öncesi eğitimi öğretmenleri ve velilerin çocuk istismarına ve ihmaline yönelik görüşleri. Yayımlanmamış yüksek lisans tezi, Selçuk Üniversitesi Sosyal Bilimler Enstitüsü.

Erol, D. (2007). Okul öncesi eğitim kurumlarında görev yapan ögretmenlerin çocuklardaki fiziksel istismar belirtilerine ilişkin farkındalıklar: Eskişehir ili örneği. Yayımlanmamış yüksek lisans tezi, Anadolu Üniversitesi Eğitim Bilimleri Enstitüsü.

Fortson, B. L., Klevens, J., Merrick, M. T., Gilbert, L. K. ve Alexander, S. P. (2016). Preventing child abuse and neglect: a technical package for policy, norm, and programmatic activities.

https://www.cdc.gov/violenceprevention/pdf/can-prevention-technical-package.pdf

Fraser, B. G. (1981). Sexual child abuse: The legislation and the law in the United States. P. B. Mrazek ve C. H. Kempe, (Ed.), Sexually abused children and their families içinde (53-74). New York: Pergamon Press.

Hart, J., Gunnar, M. ve Cicchetti, D. (1996). Altered neuroendocrine activity in maltreated children related to symptoms of depression. Development and Psychopathology, 8(1), 201-214.

Kanak, M. (2015). Okul öncesi öğretmen adaylarının duygusal ihmal ve istismara yönelik bilgi ve farkındalıklarına destek eğitim programının etkisi. Yayımlanmamış doktora tezi, Gazi Üniversitesi Eğitim Bilimleri Enstitüsü.

Karaman, Y. (1993). İlkokul öğretmenlerinin gözlemlerine göre çocukların aileleri tarafindan istismarl ve ihmali. Yayımlanmamış yüksek lisans tezi, Hacettepe 
Üniversitesi Sosyal Bilimler Enstitüsü.

Karasar, N. (2005). Bilimsel araştırma yöntemi. Ankara: Nobel Yayınları.

Kars, Ö. (1996). Çocuk istismart: nedenleri ve sonuçlart. Ankara: Bizim Büro Yayınlar1.

Kempe, C. H., Silverman, F. N., Steele, B. F., Droegemueller, W. ve Silver, H. K. (1962). The battered-child syndrome. Journal of the American Medical Association, 7(181), 17-24.

Koç, F., Aksit, S., Tomba, A., Aydın, C., Koturoğlu, G., Çetin Korkmaz, S., Aslan, A., Halıcıoğlu, O., Erşahin, Y., Turhan, T., Çelik, A., Şenol, E., Kara, S. ve Solak, U. (2012). Çocuk istismarı ve ihmali olgularımızın demografik ve klinik özellikleri: Ege Üniversitesi çocuk koruma birimi'nin bir y1llı deneyim. Türkçe Pediatri Arşivi Dergisi, 47(2), 119-124.

Krug, E. G., Dahlberg L. L., Mercy J. A., Zwi A. B. ve Lozano, R. (2002). World report on violence and health. https://apps.who.int/iris/bitstream/handle/10665/42495/9241545615_eng.pdf

Kürklü, A. (2011). Öğretmenlerin çocuk istismarı ve ihmaline yönelik farkı̄ndalık düzeyleri. Yayımlanmamış yüksek lisans tezi, Afyon Kocatepe Üniversitesi Sağlık Bilimleri Enstitüsü.

McEvoy, A. W. (1990). Child abuse law and school policy. Education and Urban Society, 22(3), 247-257.

Mcgrath, E., Keita, G. P., Strickland, B. R. ve Russo, N. F. (1990). Women and depression: risk factors and treatment issues. Washington, DC: American Psychological Association.

McIntyre, T. (1990). The teacher's role in cases of suspected child abuse. Educationand Urban Society, 22(3), 300-306.

Pala, B. (2011). Geleceğin öğretmenlerinin çocuk istismart ve ihmali konusunda bilgi ve farkındalık düzeyleri. Yayımlanmamış tıpta uzmanlık tezi, Eskişehir Osmangazi Üniversitesi Tıp Fakültesi.

Polat, O. (2007). Tüm boyutlarıyla çocuk istismarı 1 (tanımlar). Ankara: Seçkin Yayincilik.

Robbins, T. A., Stagman S. M. ve Smith, S. (2012). Young children at risk: national and state prevalence of risk factors. New York: National Center for Children in Poverty.

https://www.nccp.org/wp-content/uploads/2020/05/text 1073.pdf

Sağır, M. ve Gözler, A. (2013). Sınıf öğretmenlerinin çocuk istismarı ve ihmaline yönelik görüşleri ve farkındalık düzeyleri. Türkiye Sosyal Politika ve Çalışma Hayatı Araştırmaları Dergisi, 3(5), 67-102.

Şahin, F. ve Beyazova, U. (2001). Çocuğun şiddetten korunma hakkı. Milli Eğitim Dergisi, 151.

http://dhgm.meb.gov.tr/yayimlar/dergiler/milli_egitim_dergisi/151/sahin_beyazova.htm

Tezdiğ, C. C. (2017). Öğretmen adaylarının çocuk istismarı ve ihmaline yönelik farkındalık düzeylerinin incelenmesi. Yayımlanmamış yüksek lisans tezi, Yakın Doğu Üniversitesi Eğitim Bilimleri Enstitüsü.

Thomas, D., Leicht, C., Hudges C., Madigan, A. ve Dowell, K. (2002). Emerging practices in the prevention of child abuse and neglect. https://www.childwelfare.gov/pubPDFs/emerging_practices_report.pdf_ 
Tugay, D. (2008). Öğretmenlerin çocuk istismarı ve ihmaline yönelik farkındalık düzeyleri. Yayımlanmamış yüksek lisans tezi, Marmara Üniversitesi Sağlık Bilimleri Enstitüsü.

Turhan, E., Sangün, Ö. ve İnand1, T. (2006). Birinci basamakta çocuk istismarı ve önlenmesi. Sürekli Tıp Ĕgitimi Dergisi, 15(9), 153-157.

Türkoğlu, D. ve Gültekin-Akduman, G. (2013). Üniversitelerin okul öncesi lisans ve lisansüstü programlarında çocuk hakları dersi ve öğrenci görüşlerinin incelenmesi. Uluslararası Hakemli Aile Çocuk ve Ĕgitim Dergisi, 2(1), 56-68.

Uysal, A. ve Özsoy, S. A. (2003). Öğretmenlerin çocuk istismarı ve ihmalini içeren küçük öyküler üzerine görüş ve tutumları. Çocuk Forumu Dergisi, 6(1), 34-40.

Walsh, K., Bridgstock, R., Farrell, A. ve Schweitzer, R. (2005). Critical factors in teachers' detecting and reporting child abuse and neglect: implications for practice.

https://eprints.qut.edu.au/777/1/ACT_Complete_Report.pdf

WHO. (2017). Child maltreatment.

http://www.who.int/news-room/factsheets/detail/child-maltreatment 